\title{
Defamation AND THE MORAL COMMUNITY
}

\author{
ROY BAKER*
}

This paper presents the key findings of a major empirical investigation into defamation law and social attitudes. It examines the way in which the law decides whether a publication is defamatory, and the consequences for that process of a phenomenon known as the third-person effect: the tendency for individuals to perceive the adverse impact of a communication as greater on others than on themselves. It argues that, as a result of this tendency, defamation law unnecessarily and unfairly silences speech on the basis of protection to reputation, even though little or no reputational harm would actually occur. What is more, defamation law perpetuates regressive attitudes and could do more to promote a just and inclusive society.

\section{INTRODUCTION}

Whenever people or organisations sue, or threaten to sue, for defamation, one question always arises: have they been or are they about to be defamed? Often the defamation will seem obvious. It might even be admitted by the defendant that the publication is defamatory, in which case the parties may move on to arguing what seem more substantive matters, such as whether the allegations are substantially true, or whether some other defence to their

\footnotetext{
${ }^{*}$ Roy Baker is Lecturer in Macquarie University's Division of Law. This article reports some of the findings of the National Defamation Research Project, a major research undertaking into social attitudes and defamation law, conducted at the Communications Law Centre, formerly a research centre of the University of New South Wales. The project was financed by the Australian Research Council in conjunction with industry partners John Fairfax Holdings, the Australian Publishers Association, the Seven Network and law firm Cornwall Stodart. I acknowledge the invaluable support of the Chief Investigators of the project: Michael Chesterman, Emeritus Professor, Faculty of Law, UNSW and Professor Philip Bell, formerly Head of the university's School of Media and Communications. Thanks also go to Professor Ralph Hall of UNSW's School of Social Science and Policy, for his contribution to the design of the phone survey, the staff of the Communications Law Centre for their support (particularly Dr Derek Wilding, Therese Iverach and Jo Hobson) and the legal practitioners, judges and other residents of Australia who took part in the surveys from which this research draws.
} 
publication exists. ${ }^{1}$ In other cases the question whether the publication is defamatory remains central to the dispute, something that must ultimately be determined by a court. But whether or not this is the case, two issues are fundamental in all defamation actions. First, what imputations, if any, does the publication convey in relation to the aggrieved party? Second, does the publication, as a consequence of those imputations, meet some legal definition of defamation? Together the answers to these questions go towards determining whether the material that has been or is about to be published is defamatory of the plaintiff. ${ }^{2}$

This paper relates to how those two questions are answered. It arises from a central feature of defamation law in Australia: as a general rule neither question is answered on the basis of empirical evidence. ${ }^{3}$ Those who heard or saw a publication are rarely asked to give evidence as to what they understood it to mean, or whether, for instance, they thought less of the plaintiff as a result of their interpretation. ${ }^{4}$ Normally a plaintiff is not required to produce evidence of any actual harm resulting from the publication: a 'tendency' to harm suffices. ${ }^{5}$ Even more puzzling, a defendant is not even allowed to call proof that no harm was done in order to prove that a publication is not defamatory. ${ }^{6}$

Instead, the defamatory nature of a publication is determined on the basis of assumptions about how a hypothetical audience would interpret and react to it. But who is this hypothetical audience meant to represent? And how accurate are the assumptions made about them? Although this paper is

\footnotetext{
${ }^{1}$ Historically, Australia's laws of defamation varied substantially from state to state and from territory to territory. In the last few years, however, each state and territory has enacted new defamation laws, with the result that Australia now has a relatively uniform law of defamation (although minor differences remain). Each state and territory's statute relating to defamation sets out the available defences to the publication of defamatory material. In each case these include a defence of substantial truth (otherwise known as justification): Defamation Act 2005 (NSW) s 25; Defamation Act 2005 (Vic) s 25; Defamation Act 2005 (Qld) s 25; Defamation Act 2005 (SA) s 23; Defamation Act 2005 (WA) s 25; Defamation Act 2005 (Tas) s 25; Defamation Act 2006 (NT) s 22; Civil Law (Wrongs) Amendment Act 2006 (ACT) s 135.

${ }^{2}$ For a general introduction to Australia's laws of defamation, see Sharon Rodrick and Des Butler, Australian Media Law ( $3^{\text {rd }}$ ed, 2007) Chapter 3. Even so, Australia shares most of the elements of defamation law dealt with in this paper with England. That being the case, a more detailed description of the relevant areas of law can be found in Patrick Milmo and WVH Rogers (eds), Gatley on Libel and Slander (10 ${ }^{\text {th }}$ ed, 2004) particularly Chapters 2 and 3.

${ }^{3}$ See, eg, Charleston v News Group Newspapers [1995] 2 AC 65, 70 (Lord Bridge).

${ }^{4}$ An exception might be when the plaintiff seeks to recover special or actual damages.

${ }^{5}$ English and Scottish Co-operative v Odhams Press Ltd [1940] 1 KB 440, 461 (Lord Goddard LJ).

${ }^{6}$ Hough v London Express Newspapers [1940] 2 KB 507.
} 
concerned with these questions, ultimately it does not answer them. They cannot easily be answered, since the legal purpose behind the choice of a hypothetical as opposed to real audience as a determinant of defamation is ambiguous. Instead, I present a range of plausible interpretations of the law's purpose. I shall suggest that these are plausible in two senses: first, that all of them are substantiated by authority, at least to the extent that none of them can readily be disregarded as doctrinally wrong; secondly, that we might reasonably expect to hear any of them if we were to ask those involved with defamation law, be they lawyers, judges or jurors, as well as the actual or potential parties to proceedings, what they think the law means.

What this paper argues is that this ambiguity, as well as other features of the law, leads to unsatisfactory results. Whatever plausible interpretation we give to the law's intentions, they are not being achieved. In particular, the current law, combined with widespread misperceptions about the impact of media communications, gives rise to two undesirable outcomes. First, harm to reputation is consistently overestimated, to the unjust advantage of the plaintiff. This in turn unnecessarily and unintentionally silences harmless speech, or overcompensates for what harm is done. Secondly, defamation law can perpetuate socially regressive and exclusionary attitudes.

These conclusions derive from groundbreaking research into social attitudes and defamation. This involved a survey of 3,000 randomly-selected Australians, supplemented by focus groups held around the country involving various sections of the community, as well as extensive interviewing of judges, lawyers and journalists across four states. ${ }^{7}$ Although the research relates most directly to defamation law, the results are relevant to any field of legal practice involving perceptions of social attitudes and behaviour, particularly perceptions of how society is affected by various media. Obviously relevant areas of law include the regulation and censorship of such media content as sexual and violent images, as well as vilification laws, the tort of passing off and laws protecting courts from media influence, to name but a few.

\footnotetext{
${ }^{7}$ Judges and lawyers were interviewed in Sydney, Melbourne, Adelaide and Brisbane. Of the eight focus groups one was held in New South Wales (in Guildford, western Sydney), two in Victoria (in Moe, eastern Victoria and in central Melbourne), one in South Australia (in Black Forest, Adelaide), three in Queensland (in Ipswich, Cairns and central Brisbane) and one in the Northern Territory (in Alice Springs).
} 


\section{THE UnCERTAINTY OF THE TEST FOR DEFAMATION}

Currently there is no codified definition of what constitutes a defamatory publication in Australia. ${ }^{8}$ Instead, the common law presents various formulations of the test for defamation, all of which have one thing in common: what are determinative are perceptions of how a particular, hypothetical audience would respond to the publication if exposed to it. If it would be likely to respond in one or more specific ways then the publication is defamatory. The relevant responses have been variously described, but they generally relate to denigration of character: hatred or contempt for the plaintiffs, damage to their reputation, and so on. ${ }^{9}$ This paper is concerned less with the nature of those responses than who must be likely to exhibit them. What is the nature of the audience who must be prone to experiencing the relevant response (thinking less of the plaintiffs, hating them, and so forth) before a publication can be described as defamatory?

Two things are certain. First, as already stated, the relevant audience is hypothetical: the test for defamation is not based on the responses of those who actually heard or saw whatever material prompted the plaintiff to sue. Secondly, the relevant audience need not necessarily reflect the people whose estimation matters the most to the plaintiff, such as family, friends or customers. As put by Fleming, 'it is not sufficient that the words are regarded as prejudicial by only a small minority whose standards are so anti-social that it would not be proper for courts to recognise them'. ${ }^{10}$

Who, then, does the hypothetical audience represent? Its members are often described by two adjectives: they are 'ordinary reasonable people'. Sometimes one or both of these descriptors are replaced by terms of varying synonymy, or disappear altogether. ${ }^{11}$ Yet all the judges and defamation law

\footnotetext{
${ }^{8}$ Prior to 2006, codified definitions were to be found in the defamation law of Queensland and Tasmania: Defamation Act 1889 s 4(1) (Qld), repealed by Defamation Act 2005 s 47 (Qld); Defamation Act 1957 s 5(1) (Tas), repealed by Defamation Act 2005(Tas).

${ }^{9}$ For just a few of the most commonly cited formulations of the test for defamation see Parmiter v Coupland (1840) 6 M \& W 105, 108 (Parke B), Sim v Stretch [1936] 2 All ER 1237, 1240 (Lord Atkin), Gardiner v John Fairfax \& Sons Pty Ltd (1942) SR(NSW) 171, 172 (Jordan CJ), Youssoupoff v Metro-Goldwyn Mayer (1934) 50 TLR 581, 587 (Slesser LJ), Capital and Counties Bank Ltd v Henty (1882) 7 App Cas 741 (Lord Selbourne).

${ }^{10} \mathrm{~J}$ G Fleming, The Law of Torts (9 $9^{\text {th }}$ ed, 1998) 583.

${ }^{11}$ For instance, 'reasonable men' (Capital and Counties Bank v Henty (1882) 7 App Cas 741, 745 (Lord Selbourne)), 'man of fair average intelligence' (Slatyer $v$ Daily Telegraph Newspaper Co Ltd (1907) 7 SR (NSW) 488, 504, aff'd (1908) 6 CLR 1 (Griffith CJ)), 'ordinary men not avid for scandal' (Lewis v Daily Telegraph Ltd [1964] AC 234, 260 (Lord
} 
practitioners interviewed for this paper accepted that the phrase 'ordinary reasonable people' adequately describes the members of the relevant audience.

To call someone ordinary can, depending on context and political consciousness, be either affirming or disparaging. But there is also a quantitative aspect to 'ordinary', a word that might be understood to suggest 'majority' or 'average'. A likelihood, then, is that the relevant audience reflects a far broader community than whatever readership the offending publication enjoyed, or whoever number among the plaintiff's circle of acquaintances and business connections.

Indeed, one plausible interpretation of a legal test that speaks in terms of 'ordinary reasonable people' is to take it as a reference to general public opinion. The question then becomes how the majority of people, or the average person, would interpret the publication in question and would consequently view the plaintiff. If this were the test then quantitative research methodologies such as opinion surveys could be employed with relative ease to determine whether a publication is defamatory.

Even so, the authorities tend not to refer to majority or average opinion, but allude instead to the views of 'ordinary reasonable people', or some group similarly described. 'Reasonable' is a less obvious quantifier than is 'ordinary'. It seems more unambiguously normative, to relate more directly to intellectual and moral virtues. This is evident from the view sometimes expressed that the allusion to reasonableness exists for the protection of defendants, who should be liable only for interpretations of their publications that they ought to have anticipated, being those of the reasonable person, as opposed to outlandish readings by the unreasonable, such as those avid for scandal. ${ }^{12}$ The allusion to rationality or high morals is even more apparent when formulations of the common law test replace 'reasonable' with terms such as 'right-thinking' or 'decent'. ${ }^{13}$ There is potential for the view that such people constitute only part of the community of 'ordinary people', perhaps even a small elite. Indeed they may be 'reasonable', 'decent' or 'rightthinking' precisely because they are not ordinary.

Reith)), 'ordinary people of reasonable intelligence' (Mount Cook Group v Johnstone Motors [1990] 2 NZLR 488 (Tipping J)).

${ }^{12}$ For instance, Paul Mitchell, The Making of the Modern Law of Defamation (2005) 39-40.

${ }^{13}$ For instance 'average right-thinking man' (Tolley v JS Fry \& Sons Ltd [1930] 1 KB 467, 479 (Greer LJ)); 'right-thinking members of society generally' (Sim v Stretch (1936) 52 TLR 669, 671 (Lord Atkin)); 'ordinary decent folk in the community, taken in general' (Gardiner v John Fairfax \& Sons Pty Ltd (1942) SR(NSW) 171, 172 (Gordon CJ)). 
We now reach the ambiguity that is the concern of this paper. Two communities have emerged, either of which might be represented by the law's hypothetical audience of 'ordinary reasonable people'. The first is defined inclusively: its membership is more closely coterminous with some geographically determined population, such as all the adult residents of a particular jurisdiction. The second is more exclusive: a greater proportion of a geographically delineated population will fall outside its parameters on the basis that it fails the normative criterion of reasonableness.

The difference between 'ordinary' and 'reasonable' people, as these terms are understood by the law, may be vast, but more likely it is subtle. The point may even seem pedantic. Certainly it is rarely discussed in academic commentary on defamation law. ${ }^{14}$ What is more, our research suggests that it is not a difference considered important by judges involved in defamation litigation, nor by defamation law practitioners. But I suggest that it is worth some consideration and later I hope to argue that it reveals the full enormity of the gulf between the law's possible intentions and what, according to the research findings, are its practical outcomes.

First, however, we need to look more closely at how the law describes the relevant audience. After examining all leading decisions on the point, I submit that none offer clear guidance as to its precise nature. This paper cannot analyse all relevant judgments, but just two serve to illustrate the difficulty. First is the 1982 High Court decision in Reader's Digest Services Pty Ltd v Lamb, where Brennan J said:

\begin{abstract}
Whether the alleged libel is established depends upon the understanding of the hypothetical referees who are taken to have a uniform view of the meaning of the language used, and upon the standards, moral or social, by which they evaluate the imputation they understand to have been made. They are taken to share a moral or social standard by which to judge the defamatory character of that imputation, being a standard common to society generally. ${ }^{15}$
\end{abstract}

\footnotetext{
${ }^{14}$ For a few examples of the issue being raised, see Leslie Kim Treiger-Bar-Am, 'Defamation Law in a Changing Society: The Case of Youssoupoff v Metro-Goldwyn Mayer' (2000) 21 Legal Studies 291; Roger Magnusson, 'Freedom of Speech in Australian Defamation Law: Ridicule, Satire and Other Challenges' (2001) 9 Torts Law Journal 269; Graham Fricke, 'The Criterion of Defamation' (1958) 32 Australian Law Journal 7; Lawrence McNamara, 'Bigotry, Community and the (In)visibility of Moral Exclusion: Homosexuality and the Capacity to Defame' (2001) 6 Media \& Arts Law Review 271; Marina Lloyd Jones, 'Imputations of Homosexuality in Defamation Actions' (2001) 5(6) TeleMedia, 94.

15 (1982) 150 CLR 500, 505 (citations omitted).
} 
The reference to standards 'common to society generally' suggests that a court, in deciding what is defamatory, needs to consider the prevailing values of a geographically determined population, taking that population as a whole. It might start by looking for consensus, but if there clearly is no consensus on an issue then it would probably settle for what it perceives to be the view of the majority, or some kind of average viewpoint, in which case a survey that asks what people think and how strongly they hold those views would have obvious application.

But note the stark contrast between the above authority and a judgment delivered in the New South Wales Court of Appeal some months later, which, puzzlingly, failed to refer to the High Court decision. In Hepburn $v$ TCN Channel Nine Pty Ltd the question arose whether it is defamatory to accuse a registered medical practitioner of conducting lawful abortions. ${ }^{16}$ Hutley JA thought the argument that such an imputation is not capable of being defamatory to be 'startling':

As any abortion is regarded as wicked by a substantial part of the population on moral grounds, to say of a person that he is an abortionist may bring him into hatred, ridicule or contempt of ordinary reasonable people. ${ }^{17}$

Glass JA addressed the issue more fully and concluded:

[A] man can justly complain that words, which lower him in the estimation of an appreciable and reputable section of the community, were published to members of it, even though those same words might exalt him to the level of a hero in other quarters. Where a television programme has been beamed to a large audience it can be presumed, without special proof, that its viewers will include some who advocate the "right to life" and abhor the destruction of foetuses, whatever the circumstances. In the estimation of such persons the plaintiff can claim to have been disparaged even if abortionist meant lawful abortionist. ${ }^{18}$

Now the question is not what most people think, but what do some people think? Two layers of difficulty emerge from these and similar authorities. First, there is the lack of clarity as to how a court is supposed to choose between two approaches which I shall describe as sectionalist and majoritarian. Secondly, and more fundamentally, is the central ambiguity

\footnotetext{
${ }^{16}$ [1983] 2 NSWLR 682.

${ }^{17}$ Ibid 686.

${ }^{18}$ Ibid 694.
} 
which concerns this paper: whether the law should be understood as moralist or realist, terms I shall define once I have addressed the first difficulty.

\section{A Sectionalist and Majoritarian Approaches to Defamation}

Reader's Digest restricts the definition of defamatory publication to one that imputes to the plaintiff an act or condition that falls foul of some 'standard common to society generally'. This suggests that disapproval of the imputed act or condition must reflect some social consensus, or at least majority or average opinion within society. I shall refer to this as the majoritarian approach.

According to Hepburn, however, it can suffice that the publication might lead to damage to reputation among an 'appreciable' or 'substantial' section of the community, which presumably can include a minority. I shall call this approach sectionalism. While under Reader's Digest 'ordinary reasonable people' are typified, perhaps even defined by their response to the imputed act or condition, under Hepburn the community of 'ordinary reasonable people' is less homogeneous in its responses to the imputation, with large proportions of its members holding diametrically opposed views. Most of the judges and defamation law practitioners we interviewed favoured a majoritarian approach, but there was also substantial support for a sectionalist one.

Whichever approach is correct, an opinion poll might assist in determining what is defamatory. Under a majoritarian approach, a poll might reveal what is majority or average opinion on an issue (for instance, whether most people disapprove of doctors who perform abortions and, if so, the average strength of their disapproval). Under a sectionalist approach, a poll will help the court assess whether an 'appreciable' or 'substantial' section of the community or population would think less of the plaintiff.

\section{B Moralist and Realist Approaches to Defamation}

Note, however, that a poll only takes the court so far. It will not help in deciding whether to define the relevant community inclusively or exclusively. The problem is most apparent in Glass JA's requirement that the section of the community that would think less of the plaintiff be not just 'appreciable' but also 'reputable'. On an inclusive interpretation this additional requirement becomes relatively unimportant, so that the defamatory nature of a publication can be determined by reference to the 
views of almost any 'appreciable' section of the community, discounting only some kind of depraved or lunatic fringe. On a more exclusive interpretation, however, a greater number of sectional attitudes are disregarded on the basis that their adherents are not 'reputable'.

But there is a second, even more fundamental problem for the court: should it determine who is reputable by means of objective or subjective criteria? The term 'reputable' might be understood to mean 1) 'held in good repute', meaning that the sub-community in question is generally accepted by the broader community, or 2) 'deserving of good repute', meaning that, in the eyes of the court, the sub-community should be accepted by the broader community, even if in fact it is not. The first calls for an objective approach, the second a subjective one.

The lack of clarity as to whether the court should adopt an approach that is objective or subjective, inclusive or exclusive, extends well beyond Glass JA's sectionalist formulation of the test, whereby an imputation is defamatory if it would affect the plaintiff in the eyes of an 'appreciable and reputable section of the community'. It also arises in majoritarian statements of the law. If the determinative criterion is the view of most 'ordinary reasonable people', what weight should be given to 'reasonable'? Does the law in effect mean most 'ordinary people', which might translate as majority or average opinion? Or does the reference to reasonableness require a more exclusive approach, so that the court only considers the views of sections of the community who meet certain intellectual and moral criteria?

If the latter is the correct approach, this creates real obstacles to any attempt to apply quantitative research methodologies to defamation. Their usefulness would be far more obvious if the test for a defamatory publication were that the plaintiff's reputation would suffer in the eyes of the majority of a geographically determined population. Such a simple, objective approach could be termed realism. ${ }^{19}$ For instance, one realist statement of the law would be that a publication is defamatory if most people resident within a certain area would consequently think less of the plaintiff, even if the court takes the view that it is entirely irrational or wicked to do so. A realist court might usefully employ opinion polls, since this approach could provide the pollster with an objectively defined base population to sample and canvass.

\footnotetext{
${ }^{19}$ See the following footnote as regards my adaptation of this term.
} 
In contrast to realism is an approach that I shall refer to as moralism..$^{20}$ While the realist court is concerned with what people really think, the moralist court is also concerned with what they should think or, to be more precise, whether the relevant views meet certain thresholds in terms of rationality and morality. For instance, a moralist court might consider an imputation of homosexuality non-defamatory, even in the face of evidence of prevalent homophobia, on the basis that sexual orientation is irrelevant to a person's moral character. Under such an approach the usefulness of empirical research is clearly limited.

This basic ambiguity in the law (whether it is realist or moralist) obviously touches on larger jurisprudential issues. These will not be explored in this paper, since my purpose lies not in resolving the ambiguity but in exploring its potential outcomes in practice. It is worth noting, however, that the confusion arises in part from the tendency of judges to fail to distinguish between two potentially distinct entities. On the one hand we have what is referred to by Brennan J as 'society' and by Hutley JA as 'community' (two terms I shall treat as synonymous). On the other we have the geographically defined population, be it the adult residents of a city, jurisdiction, country or perhaps even larger area. What the common law fails to reveal is the extent to which these are coterminous. In other words, it is unclear whether membership of society or a community, as the law uses these terms, involves more than living within a certain area ${ }^{21}$ Not knowing this causes difficulties, not only for the pollster who needs a clear, objective definition of the base population but also for the court if it is to approach its task with a clear mind.

It may help to express the problem somewhat differently. It is clear from Hepburn that a publication can be defamatory when only a minority of the geographically determined population would think less of the plaintiff. So far it has been assumed that the same is not true under the test proposed in Reader's Digest. But we should open our minds to other possibilities. Brennan J in Reader's Digest required that disapproval of the imputed act or condition must be reflected in a 'standard common to society generally', which probably refers to majority or average opinion within the geographically determined population. ${ }^{22}$ But the judge also tells us that the

\footnotetext{
${ }^{20}$ I have adapted the terms 'realism' and 'moralism' from Leslie Kim Treiger-Bar-Am, above $\mathrm{n} 14$, although she uses the terms somewhat differently. There is also some similarity between my (and Treiger-Bar-Am's) concepts of realism and moralism and the ideas defined by the terms 'realism' and 'idealism' as used by Roger Magnusson, above n 14.

${ }^{21}$ For general discussion on the concept of 'community' see, for instance, Elizabeth Frazer, The Problems of Communitarian Politics - Unity and Conflict (1999).

22 (1982) 150 CLR 500, 505.
} 
relevant audience consists of 'Lord Selbourne's reasonable men or Lord Atkin's right-thinking members of society generally or Lord Reid's ordinary men not avid for scandal', these being allusions to frequently cited formulations of the test for defamation. ${ }^{23}$ This suggests that some of the geographically determined population is excluded, not least unreasonable men (and women?), non-right-thinkers and those who are avid for scandal.

The point may appear immaterial. It might seem preposterous to suggest that Brennan J means us to understand 'society' as anything other than a reference to the vast bulk of the population. But it is important to note that membership of society cannot be defined wholly by reference to geographical criteria, so that everyone who lives in a certain area is automatically a member of a particular society. The point can best be illustrated via the work of Robert Post, who has produced a particularly interesting conceptualisation of defamation law. ${ }^{24}$ For Post, defamation law operates to enforce society's interest 'in defining and maintaining the contours of its own social constitution'. ${ }^{25}$ In other words, defamation law helps to define society's parameters. To publish a defamation about someone is to challenge their right to membership, or at least full membership, of society. If it is defamatory to impute to a plaintiff a particular act or condition, then only those who are not 'guilty' of that act or condition can claim full membership of the society the law exists to serve. Those who are 'guilty' may still be members of society, but in not quite the same way, or not quite to the same extent.

If society were delineated solely by geographical criteria, so that everyone within a certain jurisdiction is a full member and all those outside are not, then the only way to defame someone would be to suggest that they do not live within the jurisdiction. Since that does not defame, but many other imputations do, this supports the proposition that the community is primarily defined by normative criteria, with individuals' membership determined by the extent to which their actions and values gain acceptance within the community. Hence it may be referred to as the 'moral community'.

That being so, it obfuscates the issue to treat the terms 'society' or 'community' as though interchangeable with 'population' (as geographically

\footnotetext{
${ }^{23}$ Ibid. The judgments being referred to are Capital and Counties Bank $v$ Henty (1882) 7 App Cas 741, 745 (re Lord Selbourne's 'reasonable men'), Sim v Stretch (1936) 52 TLR 669, 671 (re Lord Atkin's 'right-thinking members of society generally') and Lewis v Daily Telegraph Ltd [1964] AC 234, 260 (re Lord Reith's 'ordinary men not avid for scandal').

${ }^{24}$ Robert Post, 'The Social Foundations of Defamation Law: Reputation and the Constitution' (1986) 74 California Law Review 691.

${ }^{25}$ Ibid 711.
} 
defined). But this does not mean that 'society' or the 'community' cannot be defined popularly, that is? by the entire (adult) population. That is what a realist defamation court would hope to do. The fact that the defamatory nature of a publication is determined by the views and reactions of 'ordinary reasonable people' suggests that the society or community the law seeks to help define, or whose contours it seeks to maintain, to borrow Post's metaphor, consists of 'ordinary reasonable people'. Individuals who do not qualify as 'ordinary reasonable people' will number among the population, but they cannot claim full membership of the community that is the concern of defamation law.

The difference between the moralist and the realist court is that the latter adopts an objective approach when deciding who qualifies as an ordinary reasonable person, doing so by reference to the views of the entire, geographically determined population. In other words, the population decides the limits of the community. The moralist court, on the other hand, considers itself entitled to subjectively decide who falls within the community of ordinary reasonable people. For instance, it may decide to deny homophobes the status of 'ordinary reasonable people', even if it perceives homophobia as a social norm, on the basis that disparagement of homosexuals has no sound moral foundation. Thus the moralist court, not the population, determines the community.

It does not necessarily follow that realist courts will be inclusive and moralist courts exclusive when it comes to delineating the relevant community. A moralist court might consider its right to disregard the views of sections of the population, on the basis that they would respond inappropriately to the publication, as a power to be used most sparingly. It is even conceivable that a moralist court might be more inclusive than a realist court. The realist court, by definition, must adhere to popular normative standards, but if it perceives the relevant community as constituting a small but identifiable minority of the population then it would be highly exclusive. That might be the case if, for instance, the law were to define a defamatory imputation as one that would damage a person's reputation in the eyes of the 'exceptionally intelligent', in which case the task for the realist court would be to decide who, according to the general population, qualifies as 'exceptionally intelligent'.

But the test for defamation relates not to the 'exceptionally intelligent' but to 'ordinary reasonable people', and it seems fanciful to imagine that, by popular consensus, the latter phrase identifies some distinct elite. Certainly that was not a claim made during any of the focus group discussions or 
interviews conducted for this paper. For practical purposes, then, a realist court can be understood as one that equates the "community of ordinary reasonable people' with the vast bulk of the geographically determined population, excepting perhaps a few ostracised individuals who flagrantly disregard social norms. Thus a realist court is likely to tend towards an inclusive definition of the relevant community, while moralism seems to provide greater scope for exclusion.

The distinction between a moralist and a realist understanding of defamation law is likely to be subtle, but it exists nonetheless. Indeed, clear hints of these different interpretations of defamation law were apparent when we were interviewing various parties involved in defamation law. Take, for instance, the following exchange with a judge who has extensive experience of hearing defamation cases:

Would it be fair to summarise the test of what is defamatory as the opinion of the ordinary reasonable person?

Judge: Well it has to be, it's the general audience.

Who is the ordinary reasonable person? How would you describe that?

Judge: Just the ordinary man in the street. The person you sit beside on the train. They're ordinary Mums and Dads reading their newspapers, the man on the Clapham omnibus.

Is there any meaningful difference between the expression "the ordinary person" and "the ordinary reasonable person"? If we were to lose the word "reasonable", would it make any difference? Judge: Well, yes and no. The key to it is "reasonable". There are plenty of people who will read things from a prejudiced viewpoint, or looking for the worst in something. ... And there are others who take the opposite standard, it doesn't occur to them that anything unkind is being said about anybody. You talk about a reasonable person as being somebody in the middle.

In effect, then, defamation law reflects majority or average opinion. But compare this with the following from another judge, also with experience in defamation proceedings:

Judge: I don't think there's any doubt that it [the ordinary reasonable person test] is in most situations what most people would think. But ... in some special situations the law says there are particular reasons why the ordinary reasonable person is not what most people think...

Let's say that in a rural area, a slightly redneck area, a statement was made implying a person was racist towards Aboriginals. Now 
even if you knew that most people out in that area actually were rather racist themselves, I think you'd find a court would say "no, we can't take that as the standard because we can't adopt a standard that is either contrary to law in the sense of contrary to the Racial Discrimination Act, or contrary to what the court would say, I suppose, are some very fundamental moral principles".

This judge is suggesting that there are situations in which prevailing attitudes need to be discounted in order to uphold certain moral principles, the determination of which is, presumably, the job of the court.

\section{A Taxonomy of Interpretations of the Test for Defamation}

The distinct approaches of realism and moralism can now be combined with the methodologies I earlier identified as sectionalist and majoritarian to create a simple taxonomy of interpretations of the test that determines what is defamatory. First, there is majoritarian realism. The majoritarian realist court starts by deciding who falls within the community of 'ordinary reasonable people' by taking into account all views within the population. The question whether a publication is defamatory is then determined by reference to whatever attitudes are seen as prevalent in the community as thus defined. Simplified, this probably means that a publication is defamatory if most people residing in a specific area would disapprove of the imputed act or condition.

Then there is majoritarian moralism. Defamation is once again decided by an enquiry into society's prevailing views (thus the approach is majoritarian), but the court, in calculating which views prevail, discounts what it imagines to be the responses of those within the population whom the court (not the people) disqualifies as full community members on the basis that they fail to meet some threshold of morality and rationality as stipulated by the court. For instance, if the question before the court is whether it is defamatory to say of a woman that she reported her husband to the police for illegally smoking marijuana, the court might decide to discount the views of two groups: first, those who believe that it behoves a wife to behave as little more than her husband's chattel, never acting against his wishes, and, secondly, those who believe that the prohibition on marijuana should be ignored. People with these 'extreme' views might be discounted, even if they are perceived as together encompassing a majority of the population, if the court feels the need to uphold certain 'very fundamental moral principles', to quote the judge interviewed above (in this case the principles of individual 
autonomy and the rule of law). The question then becomes whether most 'ordinary reasonable people', being those with more 'moderate' views on marital loyalty and narcotics laws, would disapprove of the alleged conduct.

We can also envisage sectionalist moralism. The court decides who is contained within the community of ordinary reasonable people, but this time it suffices to render a publication defamatory if a sufficiently large section (which can include a minority) of that community would think less of the plaintiff. And finally there is sectionalist realism. Importantly this does not mean that a publication is defamatory just because some section of the population (for instance criminals) would think less of the plaintiff. Defamation law is clear that that is not so. ${ }^{26}$ But it may be defamatory if a sufficiently large number of 'ordinary reasonable people' as popularly defined, would think less of the plaintiff. So, for instance, if it could be established that people who oppose abortion are generally accepted by the general population as 'ordinary reasonable people', despite being in a minority, then under sectionalist realism an imputation relating to the procurement of an abortion is potentially defamatory.

I suggest that any plausible reading of the test for defamation falls into one of the above four categories. I also suggest that authorities consistent with all four interpretations can be found. What is more, I propose that if sufficient interviews are conducted among those people who give thought to what is defamatory, be they judges or jurors, lawyers or scholars, defamers or the defamed, then we shall find interpretations of the test that will fall into each category. Certainly that was the experience in interviewing judges and lawyers. For instance, one judge we interviewed referred to the decision in Hepburn, which supports sectionalism, as an 'aberration', citing instead Reader's Digest. Meanwhile another judge described Hepburn as 'quintessential', the locus classicus on defamatory meaning.

Just as interesting as judicial interpretations of the test for defamation are those of the general population. How might they interpret a test that refers to the 'ordinary reasonable person'? This is important for two principal reasons. First, the issue of what is and is not defamatory is still likely to be decided by a jury, and most of the adult population is eligible for jury service. ${ }^{27}$

\footnotetext{
${ }^{26}$ The point was pithily expressed by Eldridge: ' $[\mathrm{t}] \mathrm{he}$ fact that the plaintiff is lowered in the eyes of all the members of the Beneficial Burglars' Society by a statement that his reports have greatly reduced the number of professional burglars in active practice, is not defamatory of the plaintiff:' L Eldridge, The Law of Defamation (1978) 35.

${ }^{27}$ Following harmonisation of Australia's defamation laws from 1 January 2006, in all jurisdictions except South Australia, the Northern Territory and the Australian Capital
} 
Secondly, anyone might at some time be threatened with a defamation writ, or feel that they have been defamed. The way lay people interpret the 'ordinary reasonable person' test might well determine whether they fight or settle, sue or let the matter drop.

\section{AN EXERCISE IN EMPIRICALLY DETERMINING WHAT IS DEFAMATORY}

Before exploring further how lay people might interpret the law of defamation, it is interesting to conduct a straightforward empirical exercise in determining what is defamatory. For the purpose of this exercise, let us presently simplify Australia's laws of defamation so that they refer not to the views of 'ordinary reasonable people' but to those of all adults living in Australia. On that basis, we interviewed by phone 3,000 randomly selected adults resident in Australia, describing to each respondent one of ten hypothetical media reports, so that each report was described to 300 respondents. ${ }^{28}$ Each report was described so as to indicate that it imputes a particular act or condition. The ten people to whom the acts or conditions are imputed were not named or identified with any real person, but some information was given about each of them. For instance, the person imputed to have had an extramarital affair was described as a married man who holds a powerful public office. We deliberately chose media reports which were neither obviously defamatory nor clearly anodyne. The ten media reports, as described to the respondents, are listed in Table 1, alongside a concise identifier for each report.

Territory, the parties to civil defamation proceedings may, unless the court orders otherwise, elect for the proceedings to be tried by jury: eg Defamation Act 2005 (NSW) s 21 (and mirroring legislation in all jurisdictions except South Australia, the Northern Territory and the Australian Capital Territory). It is then for the jury to determine whether the defendant has published defamatory matter about the plaintiff: eg Defamation Act 2005 (NSW) s 22. In South Australia, the Northern Territory and the Australian Capital Territory all civil actions for defamation will be tried by judge alone.

${ }^{28}$ To ensure that the respondents were as representative of the population as possible, random selection of residential phone numbers was used. Interviewees were then selected from individual households by reference to which qualifying household member was next to have a birthday. The 3,000 respondents were randomly allocated to one of ten groups, each containing 300 respondents. Each group was given a description of one of the ten hypothetical media reports. 
Table 1: list of the ten hypothetical media reports as described to respondents.

\begin{tabular}{|c|c|}
\hline $\begin{array}{l}\text { Media report } \\
\text { identifier }^{29}\end{array}$ & Report description (as given to respondents) \\
\hline $\begin{array}{l}\text { Extramarital } \\
\text { Affair }\end{array}$ & $\begin{array}{l}\text { The media, while talking about a particular, named married } \\
\text { man who holds a powerful public office, have reported that } \\
\text { he has an affair with an intelligent and glamorous married } \\
\text { woman, and neither of them tells their spouse. }\end{array}$ \\
\hline Drunkenness & $\begin{array}{l}\text { The media, while talking about a particular, named } 37 \text { year- } \\
\text { old secretary in the Prime Minister's office, have reported } \\
\text { that she has got drunk at an office party and then danced on } \\
\text { the tables with her skirt lifted. }\end{array}$ \\
\hline $\begin{array}{l}\text { Marijuana } \\
\text { Use }\end{array}$ & $\begin{array}{l}\text { The media, while talking about a particular, named man, have } \\
\text { reported that he occasionally smokes a little marijuana } \\
\text { socially or for relaxation. }\end{array}$ \\
\hline $\begin{array}{l}\text { Recreational } \\
\text { Sex }\end{array}$ & $\begin{array}{l}\text { The media, while talking about a particular, named single } \\
\text { woman, have reported that she sleeps with a number of men } \\
\text { each year simply to enjoy having sex with them. }\end{array}$ \\
\hline $\begin{array}{l}\text { Informing } \\
\text { Police }\end{array}$ & $\begin{array}{l}\text { The media, while talking about a particular, named woman, } \\
\text { have reported that she has reported her husband to the police } \\
\text { because she suspects him of committing an extremely trivial } \\
\text { offence. }\end{array}$ \\
\hline $\begin{array}{l}\text { Criminal } \\
\text { Parentage }\end{array}$ & $\begin{array}{l}\text { The media, while talking about a particular, named man, have } \\
\text { reported that he has a parent who is a criminal. }\end{array}$ \\
\hline $\begin{array}{l}\text { Conducting } \\
\text { Abortions }\end{array}$ & $\begin{array}{l}\text { The media, while talking about a particular, named medical } \\
\text { doctor, have reported that she conducts lawful abortions. }\end{array}$ \\
\hline HIV Positive & $\begin{array}{l}\text { The media, while talking about a particular, named man, have } \\
\text { reported that he is HIV positive. }\end{array}$ \\
\hline $\begin{array}{l}\text { Male } \\
\text { Homosexuality }\end{array}$ & $\begin{array}{l}\text { The media, while talking about a particular, named man, have } \\
\text { reported that he is homosexual. }\end{array}$ \\
\hline $\begin{array}{l}\text { Sex Before } \\
\text { Marriage }\end{array}$ & $\begin{array}{l}\text { The media, while talking about a particular, named young } \\
\text { woman, have reported that she had a single sexual } \\
\text { relationship before getting married. }\end{array}$ \\
\hline
\end{tabular}

Once the report had been described, respondents were asked a series of questions. In particular they were asked whether, as a result of the report, they would think less of the person to whom the particular act or condition

${ }^{29}$ The identifier was not shared with the respondents. 
had been imputed. ${ }^{30}$ As expected, the proportion answering yes varied significantly depending on the imputation in question. The smallest proportion was $11 \%$ (Sex Before Marriage), the largest 56\% (Extramarital Affair). ${ }^{31}$ If we now apply a sectionalist test, so that a publication is defamatory if it would cause, say, $10 \%$ of the population to think less of the plaintiff, then all ten reports are potentially defamatory. But if a majoritarian test is employed, so that a report is defamatory only if it would cause a majority of Australia's adults to think less of the plaintiff, then the probability is that Extramarital Affair is defamatory but the others are not. ${ }^{32}$

So far we have taken as a base population all adults resident in Australia. But the law, in defining what is defamatory, typically speaks in terms of 'ordinary reasonable people'. This being so (and pretending for a moment that such empirical findings are admissible) what should a court make of the poll results? Let us assume that the court takes a majoritarian, as opposed to sectionalist view of the law, since this seems to be the orthodox interpretation of the test for defamation. That being the case, we might for present purposes interpret the answer to what is defamatory as determined by the views of most 'ordinary reasonable people'. Let us also assume that the court, when it comes to geographical delineation of the population, takes a national perspective, so that the views of adults throughout Australia are potentially relevant. Even so, the court is obliged to disregard the views of all those who fail to qualify as 'ordinary reasonable people'.

If the court is moralist, the survey will give little guidance as to what is defamatory. That is because the base population will depend on the court's subjective views as to the relevance of the imputed facts when it comes to determining a person's moral character. But if the court is realist, it will consider the views of 'ordinary reasonable people' as popularly defined. For instance, it will ask whether someone who would disapprove of the man referred to in Extramarital Affair would be generally accepted among the population as an 'ordinary reasonable person'.

\footnotetext{
${ }^{30}$ In the case of Extramarital Affair this was the man, for Recreational Sex and Informing Police it was the woman, and in the case of Criminal Parentage it was the son.

${ }^{31}$ Unless the contrary is indicated, all proportions in this paper are rounded to the nearest percentage point.

32 Since the proportion who said that they would think less of the subject of Extramarital Affair (56\%) is not much greater than $50 \%$ there is a $40 \%$ possibility that our survey respondents are unrepresentative of the population to the extent that in fact a minority of the population would think less of this person.
} 
With this in mind, respondents were asked about their perceptions of the 'ordinary reasonable person living in Australia' ${ }^{33}$ For instance, those asked for their response to the man referred to in Extramarital Affair were also asked whether they thought his reputation has been damaged in the eyes of the 'ordinary reasonable person living in Australia'. The proportion answering yes was $83 \%$. What is more, $52 \%$ of those who said they personally would not think less of the man said that nevertheless they could regard those who would think less of him as both ordinary and reasonable. ${ }^{34}$ Since people who would disapprove of the man are generally accepted as ordinary reasonable people, and since the likelihood is that the majority of the population would think less of the man, it seems clear that a realist court should consider him defamed.

But what of the other nine hypothetical media reports? In each case, a majority of respondents said they would not think less of the key person referred to therein. But does that also mean that most 'ordinary reasonable people', as popularly defined, would think likewise? The obvious answer would be yes, assuming that most people consider themselves an 'ordinary reasonable person'. If I approve, or at least do not disapprove, of certain behaviour, and if I think of myself as an 'ordinary reasonable person', it should follow that I perceive a potential for other 'ordinary reasonable people' to be similarly tolerant of the behaviour in question. Based on those assumptions, if most of the population does not disapprove of the said behaviour, it must follow that the community of 'ordinary reasonable people', as popularly defined, includes those who do not disapprove. Indeed, in the case of all reports except for Extramarital Affair, a majority of those who said they would think less of the key person in the report said that they could think of those who would not think less of that person as both ordinary and reasonable. It should follow that in the case of every report, save for Extramarital Affair, a court that adopts a majoritarian realist interpretation of the law must find for the defendant on the question of whether the report is in fact defamatory.

\section{A Comparing Public Opinion with Legal Outcomes}

Based on this opinion poll, some answers have now been given as to whether ten hypothetical reports are defamatory. Under sectionalism, any number of

\footnotetext{
${ }^{33}$ For reasons that will become apparent later in this paper, only 1,000 of the respondents (100 per media report) were asked questions relating to the response of the 'ordinary reasonable person' to the report put to them.

${ }^{34}$ These questions were put to all 300 respondents asked about Extramarital Affair.
} 
the reports might be defamatory, depending on what size section of the community must think less of a plaintiff before that person can properly be regarded as defamed. And a poll is of limited assistance if the law should be regarded as moralist. But under majoritarian realism, it has been suggested that only one out of the ten reports is defamatory: Extramarital Affair.

This finding is significant for a number of reasons. First, it was found that majoritarian realism, as defined in this paper, best encapsulates the understanding of most defamation law practitioners and judges as regards the law of defamation. That being so, special consideration is due to that interpretation of the law.

Secondly, the finding is at odds with the indications given by an analysis of trial precedents as to which of the ten reports is in practice likely to be found defamatory by a court. All ten reports were, to a greater or lesser extent, based on real publications that have formed the basis of proceedings. ${ }^{35}$ Those precedents, as well as an examination of recent reported and unreported litigation involving related imputations, indicate that, in the case of all but one of the reports, there is a realistic possibility (and in some cases probability) that a court would find the subject of the reports to have been defamed. ${ }^{36}$ This might seem a matter of concern, given that the phone survey

\footnotetext{
${ }^{35}$ The following decisions were thought to be of particular relevance: as regards Extramarital Affair: Cairns v John Fairfax \& Sons Ltd; Morosi v John Fairfax \& Sons Ltd [1983] 2 NSWLR 708; as regards Drunkenness: Bogusz v Thomson (1989) 95 FLR 167; as regards Marijuana Use: Speirs v Herald \& Weekly Times (unreported, Victoria County Court, 1988), referred to in 'Defamation Table of Quantum', Gazette of Law and Journalism, Nov 1996, 18; as regards Recreational Sex: Random House Australia Pty Ltd v Abbott, Random House Australia Pty Ltd v Costello (1999) 167 ALR 224; as regards Informing Police: Blair v Mirror Newspapers Ltd (1970) 2 DCR (NSW) 191, aff'd [1970] 2 NSWR 604; as regards Criminal Parentage: Livingstone-Thomas v Associated Newspapers Ltd (1969) $90 \mathrm{WN}$ (Pt 1) (NSW) 223 (1969, NSW Court of Appeal); as regards Conducting Abortions: Hepburn v TCN Channel Nine Pty Ltd [1983] 2 NSWLR 682; as regards HIV Positive: Serdar v Metroland Printing Publishing and Distributing Ltd [2001] OTC 318; as regards Male Homosexuality: Kelly v John Fairfax Publications Pty Ltd [2003] NSWSC 586 (unreported, Levine J, 27 June 2003); as regards Sex Before Marriage: Costello v Random House Australia Pty Ltd, Abbott v Random House Australia Pty Ltd 137 ACTR 1 (1999).

${ }^{36}$ For the relevant reports see above $\mathrm{n} 35$. All cases are Australian apart from the cases relating to HIV Positive, where only American and Canadian cases could be found, even though I am aware of at least one imputation of HIV infection (on Australian television) leading to a settlement of a defamation claim (prior to the commencement of proceedings) against an Australian publisher, which is believed to have involved the payment of damages and costs to the complainant. The one exception is Informing Police, there being authority to the effect that an imputation relating to assisting the police in the apprehension of lawbreakers is not even capable of being defamatory. The only hypothetical report where there is clear authority to the effect that the relevant imputation is incapable of being defamatory is Informing Police (see
} 
indicates that in the case of seven of the ten reports there is a less than $0.5 \%$ likelihood that a majority of Australian adult residents would think less of the plaintiff.

All kinds of explanations might be given for this disparity. Perhaps the descriptions of the publications given to the phone survey respondents did not accurately capture the essence of imputations conveyed by the original reports, or possibly social attitudes had moved on by the time of the phone survey. Even so, it is interesting to note what happened when the ten reports were described, in terms identical to those used in the phone survey, to eight judges and 28 defamation law practitioners at around the same time as the survey. ${ }^{37}$ The judges were asked two questions: first, whether they considered the hypothetical reports to be capable in law of being considered defamatory and, secondly, whether they would anticipate a finding that the reports are defamatory from a properly instructed jury. Practitioners were asked whether they would expect a judge to find the reports capable of being defamatory and whether they would predict a properly instructed jury to find the reports defamatory. In the case of six reports a majority of judges thought one or more imputations arose that were capable of being defamatory, while in the case of three reports a majority foresaw a jury verdict of defamation. In the case of eight reports a majority of the practitioners predicted that a judge would find in favour of the plaintiff on the question of capacity, ${ }^{38}$ while in the case of five of the reports at least half of the lawyers predicted a verdict of defamation from the jury. ${ }^{39}$

Again there are many potential explanations for these findings, but three are particularly worth considering. One is that the lawyers are right: the ten hypothetical reports are likely to be found defamatory, the explanation being

\footnotetext{
Blair v Mirror Newspapers Ltd (1970) 2 DCR(NSW) 191, aff'd [1970] 2 NSWR 604). It is curious, then that $82 \%$ of the 28 lawyers we interviewed thought that this report was capable of defaming the wife (who is imputed to have reported her husband to the police) and $71 \%$ predicted a jury finding of defamation.

${ }^{37}$ For details of the jurisdictions in which these interviews took place see above $\mathrm{n} 7$.

${ }^{38}$ The eight reports are Extramarital Affair (considered capable of being defamatory by $100 \%$ of the lawyers), Drunkenness (100\%), Recreational Sex (93\%), Marijuana Use (93\%), HIV Positive (89\%), Conducting Abortions (86\%), Informing Police (82\%) and Male Homosexuality (75\%). Sex Before Marriage and Criminal Parentage were both considered capable of defaming by $36 \%$ of the lawyers.

${ }^{39}$ The five reports are Extramarital Affair ( $86 \%$ of the lawyers predicting a jury finding of defamation), Drunkenness (86\%), Informing Police (71\%), HIV Positive (68\%) and Recreational Sex (50\%). As for the remaining five reports, $39 \%$ of the lawyers predicted a jury verdict of defamation for Marijuana Use, $25 \%$ for Male Homosexuality, $18 \%$ for Criminal Parentage, $11 \%$ for Conducting Abortions and 7\% for Sex Before Marriage.
} 
that courts approach defamation using a methodology other than majoritarian realism. For instance, if courts tend to adopt a sectionalist approach then it would not be too surprising if a large proportion of our media reports were found defamatory. But lengthy interviewing of the lawyers suggests that around four out of five of them (possibly more) interpret the law in accordance with majoritarian realism, with just one practitioner possibly embracing sectionalism, while most of the judges also take a majoritarian approach to the law. ${ }^{40}$

A second possibility is that the judges and lawyers tended to overestimate the proportion of the population that would disapprove of the acts or conditions imputed by the hypothetical reports. It may be that they are poor predictors of jury verdicts: they expect a verdict of defamation when juries are likely to find the report non-defamatory. But if that is so, it is interesting to note that the more experienced lawyers, who might be expected to be better at forecasting trial outcomes, were actually more likely to predict a judicial finding of capacity to defame, as well as a jury verdict of defamation, than were the less experienced lawyers. It is hard to explain why experience in defamation litigation should make a lawyer's predictions in relation to judicial findings and jury verdicts less reliable.

A third possibility, then, is that lawyers, particularly the more experienced, are relatively adept at predicting jury verdicts. It may also be that juries tend to apply majoritarian realism, meaning that they try to decide what is defamatory by reference to what most people think. Even so, it may be that jury verdicts bear little relation to community attitudes.

It is this possibility that I intend to explore further, since it would appear the most plausible. This is for various reasons. First, one would expect those with considerable experience of defamation trials to be more competent than most at forecasting how a jury is likely to respond. Secondly, our qualitative research using focus groups consisting of various sections of the community clearly suggests that lay people, when asked about the opinions of 'ordinary reasonable people', overwhelmingly tend to interpret such questions as relating to what most people think, or what the 'average' or 'typical' person thinks, this being precisely what majoritarian realism seeks to reflect. It seems likely, then, that most juries operate on the majoritarian realist model.

\footnotetext{
40 Very considerable difficulty was encountered in clearly categorising the lawyers as majoritarian or sectionalist, moralist or realist. Most seemed to have given the matter little or no thought and some would contradict themselves within the same interview when trying to describe their understanding of the law. The same applied to the judges we interviewed. Even so, majoritarian realism seemed to be favoured, particularly amongst the lawyers.
} 
So why might jury verdicts fail to reflect social values? One answer may lie in the fact that juries, like judges, are instructed, when deciding what is defamatory (and in the case of the judge, deciding what in law is capable of being defamatory), to set aside their personal values, as well as their own interpretation of the publication in question. The issue is not what the individual judge or juror thinks the publication means, nor how she or he regards the propriety of whatever it imputes, but what the 'ordinary reasonable person' would think.

The rationale behind this policy is obvious. Juries are commonly understood, at least by the judges and lawyers we interviewed, to be intended as representatives of the general community. That, surely, is a major rationale for their involvement in defamation litigation. But it does not take a statistician to appreciate that there is a real risk that a handful of jurors, let alone a single judge, will not accurately reflect society's composition. That being so, it may seem safer to ask judges and jurors to set aside their personal views. Instead of jurors being used as a sample of society, as would happen with a phone survey, jurors are employed for their knowledge of social attitudes, probably because this knowledge is perceived as superior to that of our relatively cloistered judiciary. It is understood that, statistically, jurors are unlikely to collectively constitute the fabled 'man on the Clapham omnibus', but the hope is that they will at least rub shoulders with him. That being so, jurors are not asked what they as 'ordinary reasonable people' think, but what 'ordinary reasonable people' think.

Previously in this paper, the phone survey was used as a means of gauging whether a court should find ten imaginary reports defamatory. But the poll can also be used as an indicator of what a jury is likely to make of those ten reports, given that jurors, like the phone survey respondents, are drawn from the general community. In order to do so, it was necessary to approach the phone survey respondents as a court would a jury. With that in mind, one third of the respondents were asked the kind of question jurors would be asked if the ten reports gave rise to litigation: would the 'ordinary reasonable person' think less of the subject of the report? ${ }^{41}$

Given the relatively small proportions of respondents who said that they themselves would think less of that person, the proportions who said that the

\footnotetext{
${ }^{41}$ In order to allow for 'carry-over effect' (the effect of one question on answers to subsequent questions) half of the respondents were asked about their own reaction to the media report prior to being asked about the reaction of the 'ordinary reasonable person', while the other half were asked about the 'ordinary reasonable person' first.
} 
'ordinary reasonable person' would think less of that person are staggering. For instance, just $16 \%$ of respondents said they would think less of the subject of $H I V$ Positive, but $77 \%$ predicted that the ordinary reasonable person would think less of him. As illustrated in Figure 1, a similar pattern emerged for all ten reports: in each case the proportion of respondents who considered the report put to them to be defamatory in the eyes of the ordinary reasonable person far exceeded the proportion who said that they would personally think less of the subject of the report.

Figure 1: $\quad$ Proportions of respondents indicating that the media report is defamatory in their own eyes, compared with the proportions indicating it would be defamatory in the eyes of the 'ordinary reasonable person'.

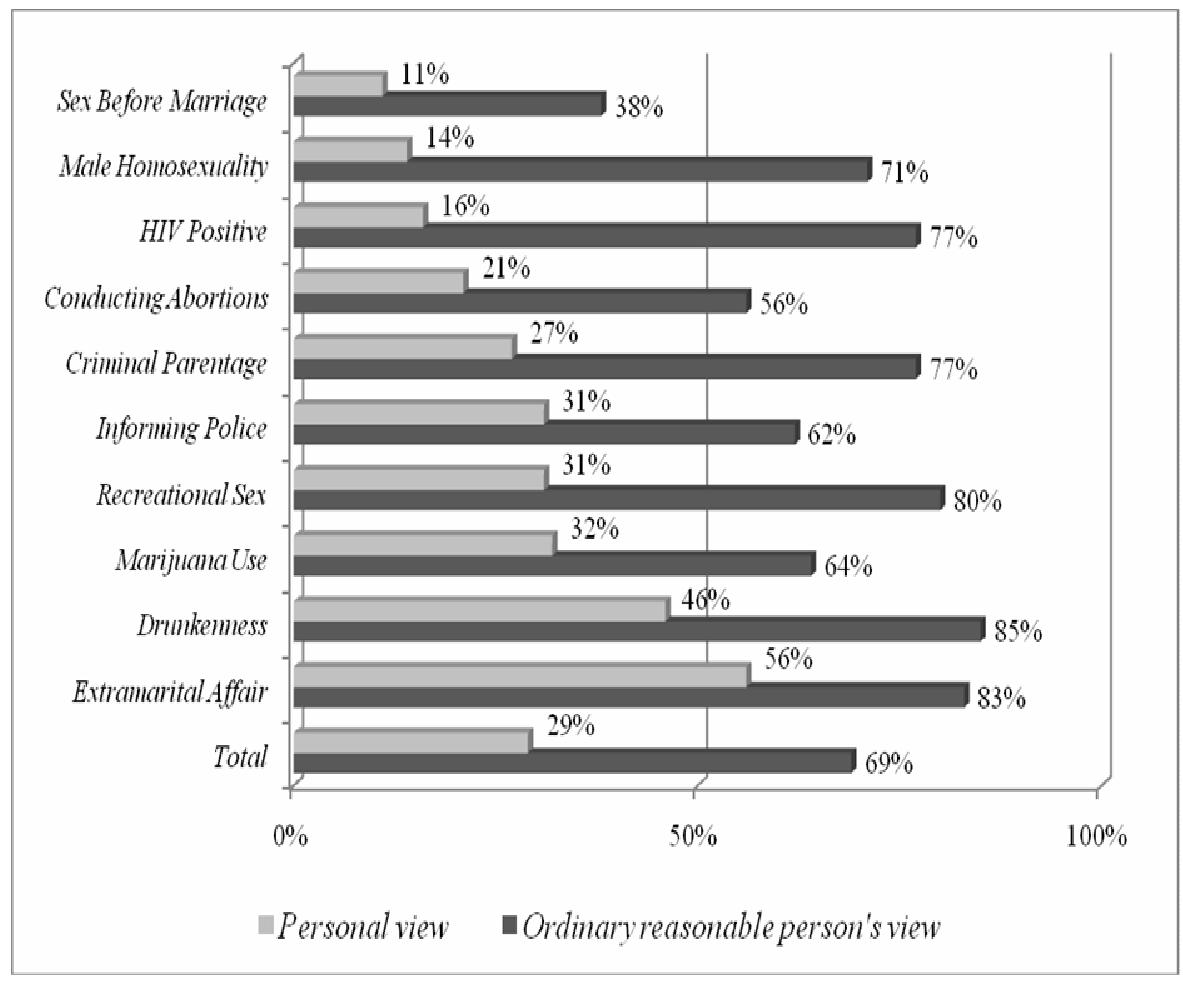

Based on these results, what verdicts should we expect from a jury that constitutes a representative sample of Australian adults? Assuming that a jury will find that a report is defamatory if a majority of its members take the view that the ordinary reasonable person is likely to think less of the plaintiff, and 
assuming that a jury consists of just four adults, ${ }^{42}$ and imagining for a moment that they are randomly selected from the entire resident adult population of Australia, as opposed to any particular region, the phone survey suggests that the probability of a jury verdict of defamation is greater than $50: 50$ in the case of eight of the ten reports. ${ }^{43}$

This outcome has to be read in the context of the two findings reported above. First, it will be recalled that in the case of eight reports a majority of the defamation law practitioners we interviewed predicted that a judge would find in favour of the plaintiff on the question of capacity, ${ }^{44}$ while in the case of five of the reports at least half of the lawyers predicted a verdict of defamation from the jury. ${ }^{45}$ What is more, the more experienced lawyers tended to predict more verdicts of defamation than their more junior colleagues. The predictions of the experienced lawyers are not vastly different from the verdicts indicated as probable by the phone survey.

Secondly, the phone survey suggests that in the case of seven of the ten reports there is a less than $0.5 \%$ likelihood that a majority of Australian adult residents would think less of the plaintiff. That being so, why might it be that the same survey, when used to predict jury verdicts, suggests that all but two reports will be found to be defamatory? If jury verdicts are meant to reflect how most Australian adults would relate to a publication, this does not appear to be the outcome. Instead, something about the jury process would seem to strongly favour the plaintiff.

\footnotetext{
${ }^{42}$ Four is the number of jurors who sit in defamation actions in New South Wales, the State with the largest number of defamation actions in Australia.

${ }^{43}$ The eight reports are Drunkenness (probability of a jury verdict: 89\%), Extramarital Affair (86\%), Recreational Sex (82\%), Criminal Parentage (77\%), HIV Positive (77\%), Male Homosexuality (67\%), Marijuana Use (55\%) and Informing Police (51\%). In the case of the two remaining reports (Conducting Abortions and Sex Before Marriage) the probability of a jury verdict of defamation is $41 \%$ and $16 \%$ respectively.

${ }^{44}$ The eight reports are Extramarital Affair (considered capable of being defamatory by $100 \%$ of the lawyers), Drunkenness (100\%), Recreational Sex (93\%), Marijuana Use (93\%), HIV Positive (89\%), Conducting Abortions (86\%), Informing Police (82\%) and Male Homosexuality (75\%). Sex Before Marriage and Criminal Parentage were both considered capable of defaming by $36 \%$ of the lawyers.

${ }^{45}$ The five reports are Extramarital Affair (86\% of the lawyers predicting a jury finding of defamation), Drunkenness (86\%), Informing Police (71\%), HIV Positive (68\%) and Recreational Sex $(50 \%)$. As for the remaining five reports, $39 \%$ of the lawyers predicted a jury verdict of defamation for Marijuana Use, 25\% for Male Homosexuality, 18\% for Criminal Parentage, 11\% for Conducting Abortions and 7\% for Sex Before Marriage.
} 


\section{B The Third Person Effect}

What has been discovered appears to be another facet of a phenomenon first identified in communications studies literature in 1983. W Phillips Davison proposed the hypothesis that individuals tend to perceive the impact of a message as greater on others than on themselves ${ }^{46} \mathrm{He}$ dubbed this the 'thirdperson effect', because media (and particularly mass media) are perceived as having their greatest impact not on 'me' or 'you', but on 'them' - the third persons.

By 1996, some 13 years after Davison's article coining the term 'third-person effect', there were 16 published studies relating to the phenomenon. According to a review of these conducted by Richard M Perloff, all but one supported the hypothesis to some extent, leading him to conclude that there is 'abundant evidence' of the effect's existence. ${ }^{47} \mathrm{~A}$ broader meta-analysis conducted in 2000 concluded that the third-person effect's perceptual hypothesis is a 'moderate to robust finding, ${ }^{48}$ This examined 32 published and unpublished studies relating to the phenomenon in such contexts as advertising, violence on television and pornography.

To date attempts to measure the relationship between the third-person effect and defamation law appear limited to three small-scale experiments conducted in the United States between 1988 and 1995. Two of these used convenience samples. ${ }^{49}$ In the case of Jeremy Cohen's research (1988), this consisted of 132 Stanford students, ${ }^{50}$ while Albert Gunther's subjects were 128 undergraduates from the University of Minnesota (1991). ${ }^{51}$ The third experiment, by Laurie Mason (1995), used 79 prospective jurors called for duty in a Californian court. ${ }^{52}$

\footnotetext{
${ }^{46}$ W Phillips Davison, 'The Third-Person Effect in Communication' (1983) 47 Public Opinion Quarterly 1

${ }^{47}$ Richard M. Perloff, 'Perceptions and Conceptions of Political Media Impact: The ThirdPerson Effect and Beyond' in Ann N Crigler (ed) The Psychology of Political Communication (1996) 177.

${ }^{48}$ Bryant Paul, Michael B. Salwen and Michel Dupagne, 'The Third-Person Effect: A MetaAnalysis of the Perceptual Hypothesis' (2000) 3(1) Mass Communication \& Society 57, 80.

${ }^{49}$ A 'convenience sample' refers to a sample used for an experiment or survey that is not expected to be representative of the population under examination. Typically it will consist of university students.

50 Jeremy Cohen et al, 'Perceived Impact of Defamation: An Experiment on Third-Person Effects' (1988) 52 Public Opinion Quarterly 161.

${ }^{51}$ Albert Gunther, 'What We Think Others Think: Cause and Consequence in the Third-Person Effect' (1991) 18(3) Communication Research 355.

${ }^{52}$ Laurie Mason, 'Newspaper as Repeater: An Experiment on Defamation and Third-Person Effect' (1995) 72(3) Journalism and Mass Communication Quarterly 610.
} 
Both Cohen and Gunther found a significant third-person effect when their subjects were asked to consider the consequences to reputation of various imaginary newspaper articles. The phenomenon was detectable even when undergraduates were asked to estimate the impact of defamatory reports on third persons as close to themselves as other students in their class. As the group whose views were to be considered became broader (such as 'public opinion at large'), so too grew the third-person effect. This being the case, we might expect a large third-person effect when individuals are asked about the 'ordinary reasonable person', given that our focus groups suggest that this is taken to be the personification of majority or average opinion. The phenomenon was also found to increase with a perception that the newspaper publishing the report was biased against the defamed party or was unreliable in its factual reporting.

Gunther reported that the third-person effect represents an overestimation of media impact on others rather than an underestimation of the same on the self. ${ }^{53}$ Cohen established the same finding when it came to media sources perceived as biased against the defamed party, but if the newspaper was seen to favour that person then the students seemed to underestimate effects on self while accurately predicting influence on other Stanford students. ${ }^{54}$ Even so, other studies unrelated to defamation tend to corroborate that the thirdperson effect involves exaggeration of impact on others rather than understatement of effect on the self..$^{55}$

Mason also found evidence of the third-person effect, but only weak support for her hypothesis that subjects are more susceptible to the phenomenon when considering a newspaper report than when thinking about the impact of interpersonal communication. ${ }^{56}$

Use of the phrase 'third-person effect' varies from writer to writer. In this paper the term is used to indicate a belief on the part of an individual ('the first person') that a specified media report will have a greater detrimental effect on the reputation of the subject of that report in the eyes of others ('the third persons') than in the eyes of the first person. For instance, people will be taken to display the third-person effect if they believe that others will be

\footnotetext{
${ }^{53}$ Gunther, above n 51, 366.

${ }^{54}$ Cohen, above n $50,170$.

55 D Lasorsa 'Policymakers and the Third-Person Effect' in J D Kennamer (ed) Public Opinion, The Press, and Public Policy (1994) 163, 167; Richard M. Perloff, 'Third-Person Effect Research 1983 - 1992: A Review and Synthesis', (1993) 5(2) International Journal of Public Opinion Research, 167, 178.

${ }^{56}$ Mason, above n 52, 615.
} 
more likely than themselves to think badly of a man as a result of a report that he is gay. People who imagine others to be less likely than themselves to think poorly of the man are said to display the 'reverse third-person effect', while those who perceive their reaction to the man as neither more nor less favourable than that of others display neither a third-person effect nor a reverse third-person effect.

Research has centred on the third-person effect as a form of collective misperception. If a large section of the population sees others as more affected by a media message than themselves, then where there is little or no countervailing tendency for individuals to see others as less affected than themselves there has necessarily been a collective misapprehension, either as to the effect on the self or as to the effect on others.

When the results for our ten media reports are aggregated, we found that $44 \%$ of respondents displayed the third-person effect when asked whether they and the 'ordinary reasonable person' would think less of the subject of the media report put to them, while less than $3 \%$ displayed the countervailing 'reverse third-person effect'. ${ }^{57}$ A further $49 \%$ displayed neither effect. ${ }^{58}$ These proportions are consistent with other surveys and experiments, which generally find that the population divides approximately 50:50 between those who display the third-person effect and those who perceive the impact of communications on others as the same as on the self. In almost every case the proportion displaying the reverse third-person effect is small to negligible. ${ }^{59}$

\section{The Third Person Effect and the 'Moral' Community}

What does the third-person effect mean for defamation law? Whatever methodology should be adopted when deciding whether a publication is defamatory, some quantification of social attitudes is involved. The thirdperson effect predicts not only that this process will be distorted, but also that

\footnotetext{
${ }^{57}$ These proportions are based on answers to the questions relating to whether the respondent and/or the third person would think less of the subject of the media report put to them. It does not include those respondents who displayed the third-person effect (or reverse third-person effect) to the extent that they indicated that they would bear antipathy towards the subject of the media report, but the third person would bear more (or less) antipathy towards the same. The proportions displaying the third-person effect or the reverse third-person effect could therefore be argued to be somewhat higher. Even so, the significant fact remains that far more display the third-person effect than show a reverse third-person effect.

${ }_{58} 5 \%$ said they did not know when asked about their own and/or the ordinary reasonable person's response to the report.

${ }^{59}$ Lasorsa, above n 55, 169.
} 
this will inevitably favour those who complain of defamation. As a consequence expression will be unnecessarily and unintentionally silenced.

This injustice comes with a particular irony, one that becomes apparent if we start to speculate as to the cause of the third-person effect. Of the countless possible explanations as to why individuals should say that they would not think less of someone in the media while the 'ordinary reasonable person' would, three stand out. The first relates to the widespread perception, strongly and repeatedly expressed during the focus group discussions, that media reports are unreliable. It may be that individuals tend to perceive the 'ordinary reasonable person' as credulous, relative to themselves, when it comes to the media. This hypothesis is supported by the findings of Cohen and Gunther to the effect that perceptions of media bias increase the thirdperson effect: bias in the media can lead to deception by the media, something that only the gullible 'ordinary reasonable person' would fall for.

The second is that, instead of (or as well as) being easily bamboozled, 'ordinary reasonable people' are understood by many of us to display a greater tendency, compared to ourselves, to choose a defamatory over an innocent interpretation for ambiguous language. Even so, the descriptions of the hypothetical media reports used in the study were designed so as to spell out the imputed conduct as clearly as possible. For instance, we explicitly referred to an extramarital affair, as opposed to alluding to it, which might have been the case if we had spoken of the man and woman 'checking into a hotel together'.

The third, and, I suggest, more likely explanation is that individuals tended to perceive the 'ordinary reasonable person' as subscribing to values according to which the imputed acts or conditions are immoral, whereas in fact they are not. For instance, someone who believes that sex should be exclusive to procreation might disapprove of the woman in Recreational Sex. Note how disparagement on the basis of most (perhaps all) of the media reports used in this experiment is likely to be associated with attitudes that are themselves widely denigrated in contemporary morality, particularly homophobia and sexism. This also became apparent from the focus groups. The attitude being expressed by the third-person effect may be 'others are homophobic, sexist and so on, but I am not'. In support of this hypothesis, note how HIV Positive produced a particularly large third-person effect. In recent decades Australia has seen public education campaigns aimed at addressing the denigration of people with HIV. Such advertising sends the message not only that denigration of those with HIV constitutes bigotry, but also that such campaigns are needed in the face of widespread prejudice. 
In short, 'ordinary reasonable people', for all their reasonableness, represent not rationality and decency but gullibility and bigotry. Indeed there seems to be a complete mismatch between how the phone survey respondents answered our questions and how courts are expected to perform. Every judge and lawyer we spoke to was of the view that judges and jurors should not decide what is defamatory by reference to their personal views. The common refrain was that they should put aside their 'prejudices', a telling word. The perception conveyed by almost every judge and lawyer was that judges and jurors will, when asked to consider community attitudes, recognise and detach themselves from their own occasional lapses into irrationality and prejudice, embracing instead common sense and basic decency. When pressed on the core values behind this shared sense of decency, there were numerous allusions to equality, tolerance and social inclusiveness. The supposition is that individuals feel a comfortable identity with and affinity for the mass of their fellow citizens. Certainly we are not perfect, but we are essentially good.

Instead, the third-person effect suggests that we see the bulk of the community somewhat differently. Instead of happily rubbing shoulders amidst civil society, we prefer to stand at or near its pinnacle, seeing the rest as stupid, bigoted or both. When asked about the 'ordinary reasonable person', our collective tendency is not to put aside our prejudices, but rather to adopt the prejudices we perceive in others.

The point can be illustrated empirically. Let us take those respondents who displayed the third-person effect, meaning those who said that the 'ordinary reasonable person' would think less of the subject put to the respondent while the respondent would not. These are the respondents who might regard themselves as particularly progressive in their attitudes to homosexuality, gender and the other issues raised in our reports. Those respondents were asked whether they felt able to consider those who would think less of the report's subject (probably those whom the respondents see as less progressive than themselves) as ordinary and reasonable. ${ }^{60}$ These, surely, are the two qualities we would expect of the 'ordinary reasonable person'.

Only $43 \%$ of these 'progressive' respondents said that they felt able to consider those who would think less of the subject of the report as both

\footnotetext{
${ }^{60}$ In order to allow for 'carry-over effect' (see above, $\mathrm{n} 41$ ) half of the respondents were asked whether they could think less of those who disagreed with them about whether to think less of the subject of the report as 'ordinary' before being asked whether they could think of such people as 'reasonable', while for the other half the order of these two questions was reversed.
} 
ordinary and reasonable. Around $30 \%$ said they could regard such people as ordinary but not reasonable, while just $4 \%$ said they could think of them as reasonable but not ordinary and just $15 \%$ could think of them as neither ordinary nor reasonable.

We now encounter an apparent incongruity. Of those respondents who identified disapproval as the response of the 'ordinary reasonable person', a large proportion ( $49 \%$, in fact) went on to say that they could not think of people who would disapprove as ordinary and reasonable. In other words, people who think like the 'ordinary reasonable person' are neither 'ordinary' nor 'reasonable'!

What seems to be happening is that, for a large proportion of the population, the phrase 'ordinary reasonable person' takes on a meaning that has little to do with its constituent adjectives, particular the second ('reasonable'). To many the 'ordinary reasonable person' represents whatever is perceived as typical of the population. This was the view repeatedly expressed during focus groups: it was clear that questions about the 'ordinary reasonable' person were frequently understood as questions about majority or average opinion. Those who indicated that the 'ordinary reasonable person' is not 'ordinary' or not 'reasonable' were presumably expressing disapproval of what they perceive to be public opinion. Almost half of the people who displayed the third-person effect seemed to do this by denying people who think in accordance with public opinion the accolade 'reasonable'. It would seem logical for an individual to do this if they identify public opinion as irrational or bigoted, but it is paradoxical that $19 \%$ of respondents displaying the third-person effect appeared to be indicating that people who ascribe to what those respondents decry as public opinion are not 'ordinary'. Perhaps the explanation lies in the ability of 'ordinary' to constitute an affirmation, not unlike 'reasonable'.

\section{The Third Person Effect and the 'Reasonable Person'}

Although 'ordinary' can be an accolade, it is less unambiguously positive than 'reasonable'. It has been suggested that the law inserts reasonableness into the test so as to rule out perverse readings of text, since publishers should only be held accountable for sensible interpretations of their works. ${ }^{61}$ Indeed, it was clear from focus group discussions that reasonableness and ordinariness are not understood as synonymous, and the distinction is

\footnotetext{
${ }^{61}$ For instance, Mitchell, above n 12, 39-40.
} 
supported by the quantitative research, which suggests that it is easier to qualify as 'ordinary' than it is to qualify as 'reasonable'. Accordingly, $73 \%$ of respondents said that, as regards those who would disagree with their evaluation of the imputed act or condition, the respondents could think of those people as 'ordinary', while just 58\% could think of them as 'reasonable'.

Consistent with those results would be a finding that omission of the quality of reasonableness from the test for defamation would increase the thirdperson effect. That would be because people would prefer to identify with the hypothetical 'reasonable person' than with the 'ordinary person', meaning that they would be more likely to perceive the former's response to a publication as similar to their own.

In order to test that hypothesis, the exercise described above was repeated with a further 2,000 respondents, but this time the description of the "third person' (previously termed the 'ordinary reasonable person') was varied. ${ }^{62}$ One thousand respondents were asked to predict the response to one of the ten media reports of the 'ordinary person living in Australia' as well as their own, while a further 1,000 respondents were asked about the 'reasonable person living in Australia'. ${ }^{63}$

The results were anything but expected. Table 2 shows the proportions of respondents displaying the third-person and reverse third-person effect in relation to the three 'third persons' (the 'ordinary', 'reasonable' and 'ordinary reasonable' person) used in the survey. As can be seen, these are virtually identical. ${ }^{64}$ These aggregated results mask considerable variations in relation to individual reports, but even so our results suggest there would be no overall marked reduction in the third-person effect if the description of the relevant audience underwent such modifications.

\footnotetext{
${ }^{62}$ In other respects all survey conditions were identical to those described above.

${ }^{63}$ As with those respondents asked about the responses of the 'ordinary reasonable person', question order was varied so as to allow for 'carry-over effect' (see above n 41 and 60).

${ }^{64}$ There are no statistically significant differences between the three groups.
} 
Table 2: $\quad$ Proportions of respondents displaying third-person effect and reverse third-person effect when asked whether they and/or the third person would think less of the subject of the media report: all reports and third persons aggregated. ${ }^{65}$

\begin{tabular}{|l|c|c|c|c|}
\hline $\begin{array}{l}\text { Description of the third } \\
\text { person }\end{array}$ & $\begin{array}{c}\text { Ordinary } \\
\text { person }\end{array}$ & $\begin{array}{c}\text { Ordinary } \\
\text { reasonable } \\
\text { person }\end{array}$ & $\begin{array}{c}\text { Reasonable } \\
\text { person }\end{array}$ & Totals \\
\hline $\begin{array}{l}\text { Proportion displaying } \\
\text { third-person effect. }\end{array}$ & $43 \%$ & $42 \%$ & $42 \%$ & $42 \%$ \\
\hline $\begin{array}{l}\text { Proportion displaying } \\
\text { reverse third-person effect. }\end{array}$ & $2 \%$ & $3 \%$ & $3 \%$ & $3 \%$ \\
\hline $\begin{array}{l}\text { Proportion perceiving the } \\
\text { third person's reaction to } \\
\text { the report as the same as } \\
\text { their own. }\end{array}$ & $49 \%$ & $49 \%$ & $50 \%$ & $49 \%$ \\
\hline $\begin{array}{l}\text { Proportion answering } \\
\text { don't } k n o w \text { ' in relation to } \\
\text { their own and/or the third } \\
\text { person's reaction to the } \\
\text { report. }\end{array}$ & $6 \%$ & $7 \%$ & $6 \%$ & $6 \%$ \\
\hline
\end{tabular}

Even so, might a change in the description of the relevant audience affect defamation law outcomes? If we again aggregate the results for our ten media reports, our findings suggest that changing the description? from 'ordinary reasonable person' to 'reasonable person' would have so little general effect that it is not even statistically discernable from our results. Overall, retaining the reference to reasonableness seems to favour defendants, but the benefit is marginal. Of the 1,000 respondents asked about the 'ordinary reasonable person living in Australia', 69\% thought that this person would think less of the subject of the report described to them. Of the 1,000 asked about the 'ordinary person living in Australia', the proportion anticipating disapproval

\footnotetext{
${ }^{65}$ In this table account is taken only of the third-person effect or reverse third-person effect displayed in answering whether the respondent and the third person would think less of the subject of the report described to the respondent. It does not include the proportion of respondents displaying either effect in that, while perceiving the third person as well as themselves as thinking less of the subject, the respondent expected the third person to think even less of the subject than would the respondent (in the case of the third-person effect), or expected the third person to feel less disapproval than would the respondent (who would feel some) in the case of the reverse third-person effect.
} 
was $74 \%$, an increase that, although statistically significant, is hardly striking. ${ }^{66}$

\section{CONCLUSION}

I began this article by pointing to an ambiguity in the law of defamation. When the law asks us to consider what response a publication is likely to produce in a hypothetical audience, it is unclear whether those responses are intended to reflect majority or average opinion within the population. What is also far from apparent is the extent to which a judge or jury is entitled to disregard potential responses that the judge or jury (as opposed to public opinion) considers irrational, immoral or both. The proposition that they are entitled to do so derives from authorities that describe the constituents of the relevant hypothetical audience as 'reasonable', a term sometimes replaced by 'decent', 'right-thinking', 'sensible' or some such term.

Despite this ambiguity, some things are apparent. The intention behind the test for defamation is to reflect attitudes and values held by at least a substantial or appreciable section of the community. Indeed, most of the lawyers and judges we interviewed thought that those attitudes and values should be prevalent in society. Even more obvious, the test is not meant to discount attitudes and values on the basis that they are perceived to be reasonable, decent, right-thinking or sensible. To suggest otherwise is patently absurd.

Even so, the evidence presented by this paper suggests that that is precisely the outcome of the test. This is based on the supposition that it is the subjective view of most of us that our own values are reasonable, decent and so on. Assuming also that juries and judges are just as likely to display the third-person effect as the respondents to the phone survey (and there is no obvious reason to think that this is not so), it would seem that, in deciding whether a publication is defamatory, many of those judges and juries set aside their own views on the imputed conduct, just as they are meant to. But what they tend to substitute for attitudes that they perceive as reasonable and decent are responses to the publication that they would attribute to someone who is gullible, prejudiced or both.

The problem is that the law anticipates what in this paper has been identified as the reverse third-person effect: the setting aside of personal idiosyncrasies or 'prejudices' in favour of whatever is perceived as ordinary, reasonable

${ }^{66} p<.02$. 
opinion. But the tiny proportion who display the reverse third-person effect is vastly outweighed by the much larger proportion who display the countervailing third-person effect. The consequence is that the hypothetical audience that decides what is defamatory consists of whoever is perceived as lacking good judgment. That audience becomes a bunch of idiotic bigots, not the 'ordinary reasonable people' the law has in mind. I have suggested that most judges' and practitioners' interpretation of the test for defamation can be characterised as majoritarian realism. But the phone survey suggests that what actually happens is the precise opposite. It might even be called sectionalist immoralism: defamation law gives voice not to society's prevailing attitudes as to what is rational and moral, but rather to minority attitudes that are archaic at best, bigoted at worst.

The cost of the third-person effect is borne not only by publishers who face the burden of defending material which should never have been considered defamatory in the first place. The phenomenon is detrimental to all of us. First, it inevitably limits our right to communicate and access information and ideas that are anticipated to damage reputation, even when such damage would in fact be far less than imagined. Secondly, for those who identify the 'ordinary reasonable person' as a personification of public opinion, statements by lawyers or courts to the effect that a publication is defamatory will tend to enforce misconceptions about prevailing attitudes.

Thirdly, the third-person effect obfuscates the types of values that the law endorses as reasonable. That is because some people will interpret legal findings in relation to the 'ordinary reasonable person' not as empirical statements relating to public opinion but as normative claims about what a reasonable person should (as opposed to does) think. Every time a lawyer claims, or a court finds that the 'reasonable person' disparages homosexuality, HIV infection, or any of the other acts or conditions imputed by the ten media reports used as the basis of this research, those views are entrenched as legally sanctioned. To that extent, defamation law retards progress towards a more just and tolerant society. It will continue to do so for as long as the law's arbiter of defamation, the 'ordinary reasonable person', is identified with the irrational bigot, the sexist and the homophobe, precisely the person most of us least want to be. 
